\title{
The energy potential of soft rush (Juncus effusus L.) in different conversion routes
}

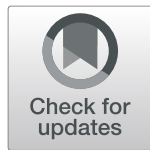

\author{
Jürgen Müller ${ }^{1 *} \mathbb{D}$, Christian Jantzen ${ }^{2}$ and Denny Wiedow ${ }^{2}$
}

\begin{abstract}
Background: Rushes are prominent wetland plants that are well adapted to conditions of waterlogging. Tall rushes like soft rush (Juncus effusus L.) tend to dominate the vegetation and offer a great biomass potential. Removing rush biomass is often necessary to enhance various ecosystem services of wetlands. There is an urgent need for sustainable use of the removed biomass apart from expensive composting ore useless landfill.

Methods: We investigated three alternative energy utilisation routes for soft rush biomass and evaluated their energetic potential: biomethanisation via wet fermentation technique (a), biomethanisation via solid-state fermentation technique (b) and combustion (c). Batch experiments (a), experimental fermenters (b), and thermocalorimetric equipment (c) were used to measure energy output per unit rush biomass input.

Results: The wet fermentation technique had significantly higher biogas yields than solid-state fermentation (399 $\mathrm{L}_{\mathrm{N}} \mathrm{kg}^{-1}$ oDM compared to $258 \mathrm{~L}_{\mathrm{N}} \mathrm{kg}^{-1} \mathrm{oDM}$ ). These yields constitute 59 and 43\%, respectively, of the biogas potential of maize silage as a reference. Solid-state fermentation technique needs longer retention time compared to wet co-digestion to earn comparable methane yields. Soft rush biomass shows high heating values (15.06 MJ kg $\mathrm{FM}_{\mathrm{w} 15}{ }^{-1}$ ) compared to other herbaceous solid fuels.

Conclusions: Low costs for substrate production make energetic utilisation of Juncus effusus an interesting alternative, if short distances between fields and biomass conversion plant can be realised. All investigated conversion routes appear promising, provided that the substrate specifics are considered in the design of the conversion technique. Besides the size of the rush dominated area and the distribution of these areas in the landscape, the investment costs and the subsidies for the conversion plant play a pivotal role in the selection of the preferred conversion path.
\end{abstract}

Keywords: Wetland biomass, Soft rush, Energetic conversion, Biogas, Direct thermal utilisation, Solid-state fermentation, Wet co-digestion

\section{Background}

Rushes are prominent wetland plants of the genus Juncus, occurring with more than 200 species worldwide in a broad range of habitats [1]. Most of them are helophytes and well adapted to conditions of waterlogging [2]. Soft rush (Juncus effusus L.) is a perennial, tussock-forming

\footnotetext{
* Correspondence: juergen.mueller3@uni-rostock.de

${ }^{1}$ Grassland and Forage Science, Faculty of Agricultural and Environmental Sciences, University of Rostock, Justus-von-Liebig-Weg 6, 18059 Rostock, Germany

Full list of author information is available at the end of the article
}

and tall growing member of that genus [3, 4]. Juncus effusus is widespread throughout subtropical, temperate and boreal regions [3] and often provides crucial eco-system services in natural peat- and wetlands [5-7]. However, if peatlands are meliorated and used for ruminant husbandry, the dominant macrophyte soft rush is regarded as a weed [8] due to its low forage value and high infestation potential [9]. Tall rushes like Juncus effusus have the capacity to dominate the vegetation [10], especially under periodically wet conditions and extensive grazing [11]. Both properties, providing ecosystem services in natural

(C) The Author(s). 2020 Open Access This article is licensed under a Creative Commons Attribution 4.0 International License, which permits use, sharing, adaptation, distribution and reproduction in any medium or format, as long as you give appropriate credit to the original author(s) and the source, provide a link to the Creative Commons licence, and indicate if changes were made. The images or other third party material in this article are included in the article's Creative Commons licence, unless indicated otherwise in a credit line to the material. If material is not included in the article's Creative Commons licence and your intended use is not permitted by statutory regulation or exceeds the permitted use, you will need to obtain permission directly from the copyright holder. To view a copy of this licence, visit http://creativecommons.org/licenses/by/4.0/ The Creative Commons Public Domain Dedication waiver (http://creativecommons.org/publicdomain/zero/1.0/) applies to the data made available in this article, unless otherwise stated in a credit line to the data. 
wetlands and driving out forage grasses in extensively managed peatlands for conservation goals, can be attributed to the impressive viability, the robustness against high iron and sulphide concentrations [12] and the remarkable biomass potential of this species. Tall rush dominated stands can reach aboveground biomass yields more than $10 \mathrm{t}$ dry matter per ha $[4,13]$.

Despite this ecological performance, rushes have not played a notable role as cultivated crops in paludiculture until now [14]. However, Coleman et al. [15] and Menon and Holland [16] found soft rush suitable as a remediation plant in constructed wetlands. Syranidou et al. [17] highlighted the successful contributions of Juncus effusus to clean wastewater in detail. Using rushes as phytoremediation plants can also lead to high yielding stands depending on stress level and nutrient load in the sewage. A removal of biomass enhances proper functionality of sewage clearing in some constructed wetlands [18]. Solutions for further treatment of removed biomass outside organic waste landfills have to be found.

Removing rush biomass is often necessary in seminatural and extensively used wet grasslands too to enhance the ecosystem services for a variety of reasons like the removal of nutrients [19], reduction of competition [20] or providing habitats for birds [21]. Rush provides almost no value for livestock feeding [22], and if rush stands need to be harvested, it makes sense to utilise the incidental biomass in different ways. A broad scale of technical opportunities for such biomass utilisation in biorefinery exists [23]. Nevertheless, the use for energy purposes seems to be the most promising one $[24,25]$. In contrast to the economically superior energy plant maize, rush biomass from wetlands also shows ecological benefits and helps to avoid the food vs. energy conflict [26].

Under the current economic conditions, the procedures of combustion [27] as well as the transformation into biogas [28] are the most viable converting technologies for wetland biomass. These two basic conversion routes place specific, different demands on the biomass properties, which have to be regarded in different technological conversion procedures. While combustion technologies require biomasses with restricted amounts of minerals and $\mathrm{N}, \mathrm{S}, \mathrm{Cl}$ compounds in the dry matter [29] and can use lignocelluloses well [30], biomethanisation is sensitive to high lignified fibre and inhibitive secondary plant compounds in the feed stuff too [31]. Except for the studies of Corton et al. [32], Hensgen et al. [33] and Joseph et al. [34], where biomasses with high amounts of rushes were included, no further conceptual investigation concerning the preferred use of rush biomass according to its contents and material conditions could be found in the relevant scientific databases (ScienceDirect, SCOPUS, Web of Science). This study aimed at filling the gap of knowledge by analysing the use of rush biomass for energy purposes in different utilisation routes.

The specific questions we addressed against this general background were as follows:

(I) Which conversion route-combustion, wet fermentation or solid-state fermentation is practicable for biomass from Juncus-dominated wet grasslands? (II) Which energetic conversion efficacy of the biomass can be attained by the different technologies applied? (III) Which technique should be preferred?

\section{Material and methods \\ Substrates}

Substrates for the conversion techniques were sampled at different peaty grassland areas in Northern Germany where soft rush dominates vegetation coverage. The substrate collections were carried out separately for each of the three conversion routes. In every case, late summer to early autumn sampling dates were chosen to be in line with the common practice of biomass harvest under landscape preservation conditions. Soft rush coverage of the site and standing biomass was roughly estimated using a compressed-height calibrated plate meter (Herbometre ${ }^{\circ}$, INRA, France). We harvested the biomasses for both fermentation experiments with motor scythes and for the combustion experiments with a commercial grass shear. An overview of site characteristics, substrate origin, conditioning and further experimental usage is given in Table 1.

Percentage of senescent plant materials in the rush bulks was visually estimated. Rush-dominated stands were cut at a stubble height of $5-7 \mathrm{~cm}$ above ground. Thereafter, non-rush plant biomass was separated from the collected harvest stocks. The separated soft rush material was then chopped by hand and mixed afterwards. The biogas feedstocks dedicated for the solid-state fermentation experiments were ensilaged in plastic tubs with an ensiling duration of 90 days. In the case of wet fermentation batch trials, the chopped rush substrate was frozen at $-22{ }^{\circ} \mathrm{C}$ and defrosted immediately before batch series starts. A representative sample of $500 \mathrm{~g}$ fresh matter from the soft rush biomass was dried for further chemical Weender analysis including crude fibre $(\mathrm{CF})$, crude protein $(\mathrm{CP})$ and enzyme-insoluble organic substance (EULOS) determination according to Naumann and Basler [35]. Dry combustion technique (Elementar Analyzer, Vario Max CNS, Elementar ${ }^{\circ}$, Germany) has been adapted to determine total carbon (C) and sulphur (S) contents.

\section{Methods}

\section{Batch wet co-fermentation test}

We used a mini batch test according to the VDI Guideline 4630 [36] as the standard to simulate a 
Table 1 Origin and some field characteristics of the rush biomass collected for the different energy conversion experiments

\begin{tabular}{|c|c|c|c|c|c|}
\hline Location & $\begin{array}{l}\text { Biomass yield (t } \\
h \mathrm{ha}^{-1} \text { ) }\end{array}$ & $\begin{array}{l}\text { Amount of harvested material } \\
\text { (kg FM) }\end{array}$ & $\begin{array}{l}\text { Amount of senescent material } \\
(\% \mathrm{FM})\end{array}$ & $\begin{array}{l}\text { Conversion } \\
\text { experiment }\end{array}$ & Substrate conditioning \\
\hline$\overline{D a r} \beta$ & $2.0-4.0$ & $\sim 500$ & $5-30$ & $\begin{array}{l}\text { Solid-state } \\
\text { fermentation }\end{array}$ & Silage from pure rush biomass \\
\hline Rendsburg & 3.5 & $\sim 25$ & $\sim 12$ & Wet fermentation & $\begin{array}{l}\text { Fresh rush biomass, thawed after } \\
\text { freezing }\end{array}$ \\
\hline Rostock & 2.8 & $\sim 2.5$ & $\sim 7$ & Combustion & Fresh rush biomass, air-dried \\
\hline
\end{tabular}

discontinuous wet fermentation under mesophilic temperature conditions. Gas-tight 1-1 bottles served as reactors. They were heated up to the desired temperature of $38^{\circ} \mathrm{C}$ by placing them in a temperaturecontrolled water bath (see Fig. 1a). The formed biogas was channelled into gasbags and the volume was determined by drum gas meters (TG, Ritter ${ }^{\circ}$, Germany). Because of the small amounts of substrate and consequently of biogas too, the time of the qualitative gas analysis was determined by a minimum threshold of $500 \mathrm{ml}$ produced biogas.

The substrates were inoculated with decomposed fermentation residue from a biogas plant by a mass ratio of $<0.5$ referred to the content of organic substance $(\mathrm{w} / \mathrm{w})$. After starting the fermentation in three replications, the formed gas volumes and external conditions were recorded daily. The biogas composition $\left(\mathrm{CH}_{4}, \mathrm{CO}_{2}, \mathrm{O}_{2}\right)$ was determined with a biogas monitor (bm 2000, Ansyco $^{\circ}$, Germany) if sufficient biogas was available. After a holding time of 35 days, the biogas yield of the soft rush substrate was calculated and corrected to standard volumes taking the environmental conditions, the biogas yield of the inoculum and the methane proportion into account.

\section{Batch solid-state fermentation test}

A pilot solid-state fermentation plant with high reactor volumes was chosen for the test. We used reactors with a net usable volume of app. $70 \mathrm{l}$ for the fermentation of soft rush silage as a single substrate (see Fig. 1b). The

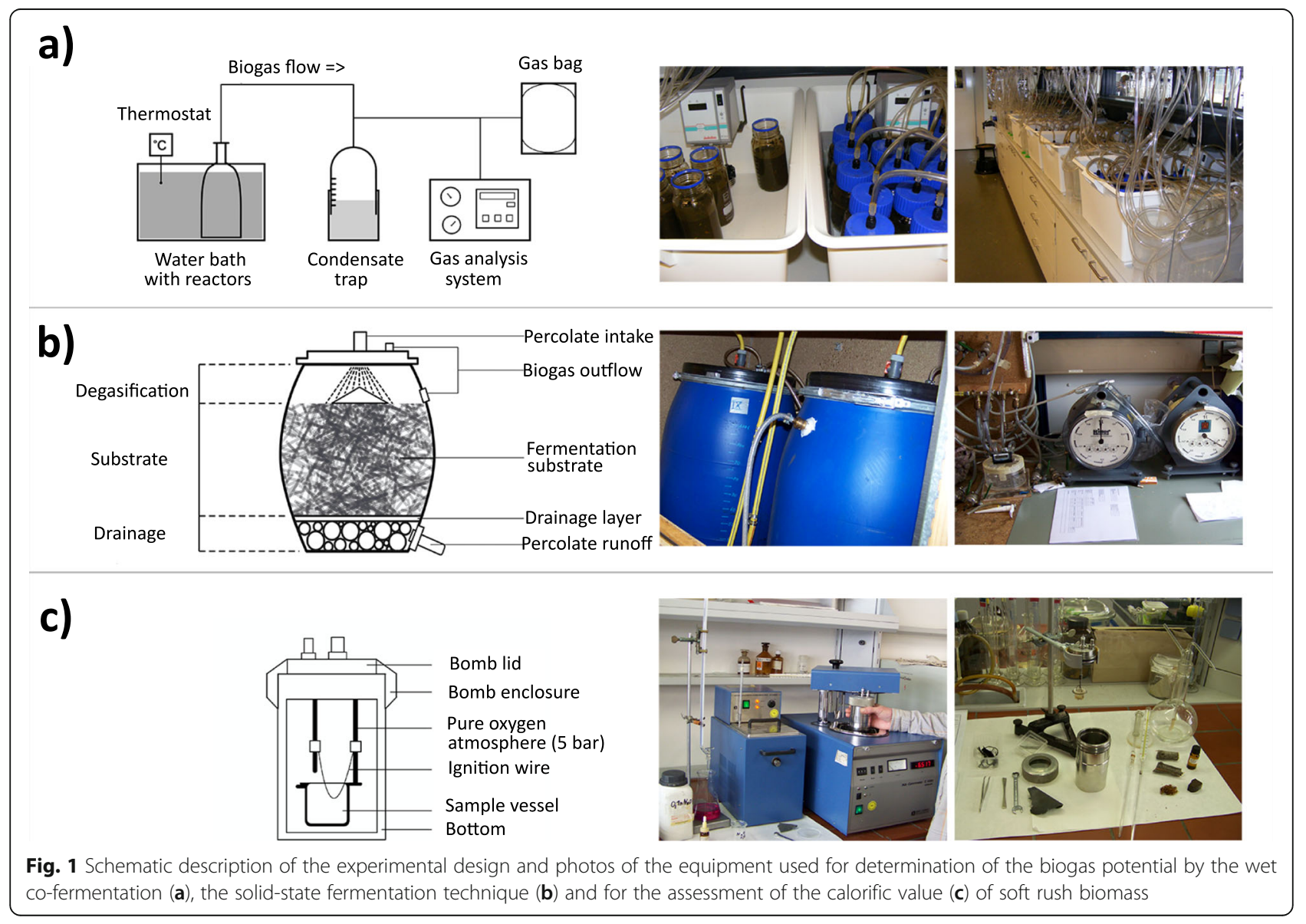


desired mesophilic reaction temperature was achieved via a thermostat-controlled heater. The percolation liquid of every reactor is stored in single heated and stirred $30 \mathrm{l}$ percolate-tanks, from which the process liquid gets pumped and distributed over the substrate stock. The organic acid-enriched percolate leaves the reactor and flows back in the storage tank, whereby a small proportion flows into the sampling nozzle. The formed biogas flows through the gas hose to a measurement place. Each reactor was assigned to a gas sampling nozzle and a drum gas meter. Temperature sensors were used to measure the gas temperature prior entering the drum gas meter. An additional installed sensor recorded the prevailing ambient temperature and the air pressure enabling us to convert the measured biogas flow rates into standard litres. According to the plant operator guidelines, a two-time percolation of $15 \mathrm{l}$ per day was applied after an initially substrate jamming with the entire available percolate. The residence time of the first test run was 43 days, that of the second 61 days. Both runs were repeated twice. We controlled the fermentation process by regular measurements of the $\mathrm{pH}$ value and the ratio of organic acids to buffer capacity (FOS/ TAC ratio). Total daily dwell, the resulting biogas volume, its composition $\left(\mathrm{CH}_{4}, \mathrm{CO}_{2}, \mathrm{O}_{2}\right)$ and the prevailing conditions were recorded. Biogas and methane yields were calculated based on the recorded values of gas volumes and concentrations, corrected to standard conditions (norm litres at $273 \mathrm{~K}$ and $1013 \mathrm{hPa}$ ) [36].

\section{Combustion}

The fuel technical properties of purely soft rush where determined by using a bomb calorimeter (see Fig. 1c). A thermo-gravimetrical analysis (TGA) was conducted, where a small amount of the sample (max. $200 \mathrm{mg}$ ) was filled into an inert melting pot that is surrounded by a furnace unit and connected with a highly sensitive lab balance. A computing component controlled the target temperature programme and recorded the weight loss. The temperature programme was adjusted according to the German engineering standards DIN 51718 (water content) [37], DIN 18123 (volatile matter) [38] and DIN 51719 (ash content) [39]. The proportion of solid fuel (Cfix) was calculated as the difference between the weight of the original sample and the summed proportions of volatile components, water and ashes in accordance with DIN 18123. To classify the determined parameters, the test series were complemented by analyzing well-known regenerative fuel biomass as well as added herbaceous biomass under the same conditions. To ensure similar conditions, all samples were dried under force-vented laboratory conditions and ground up to a particle size $\leq 0.5 \mathrm{~mm}$ afterwards.

\section{Energy content}

The energy content was analysed by the usage of an adiabatical bomb calorimeter according to DIN 18125 [40]. With this technique, a soft rush sample was completely combusted under a high-pressure oxygen atmosphere. The released thermal energy heated up a surrounding water bath. Regarding the starting and finishing temperature of the water and the specific thermal capacity of the used bomb, the gross calorific value $\left(\mathrm{H}_{\mathrm{s}}\right)$ can be calculated.

To determine the net calorific value $\left(H_{i}\right)$ of the samples with a given water content, the thermogravimetrically and calorimetric analyses were performed at the same time. $H_{s}$ and $H_{i}$ were corrected to the water free $(w f)$ as to the water and ash free (waf) basis (Eq. 1 and 2) taking into account the water and ash content from the thermo-gravimetrically analysis. Every thermogravimetrical and calorimetric analysis of each samples had been repeated twice consecutively.

$$
\begin{aligned}
& H s, H i(w f)=\frac{H s, H i \times 100}{100-w} \\
& H s, H i(w a f)=\frac{H s, H i \times 100}{100-w-a}
\end{aligned}
$$

\section{Comparative parameters}

We use two different approaches to compare the different conversion paths with each other. The first one, the 'Specific biogas yield potential', is limited to both biodigestive methanation processes. The second, the 'Heat generation potential', follows a broader approach.

\section{Specific biogas yield potential}

We compared wet and solid-state fermentation techniques with the help of the specific biogas yield potential according to Weißbach [41]. We used the extent to which the nutritive-justified fermentation potential of the test substrate has been achieved as a benchmark for the conversion suitability of the process.

The potential for methane formation was estimated based on biochemical parameters of the substrates before ensiling as follows:

$$
\begin{aligned}
& \mathrm{VS}=1000-(\mathrm{CA})-0.62(\mathrm{EULOS})-0.000221(\mathrm{EULOS})^{2} \\
& \mathrm{BGY}=0.80(\mathrm{VS}) \\
& \mathrm{CH}_{4} \mathrm{Y}=0.42(\mathrm{VS})
\end{aligned}
$$

BGY and $\mathrm{CH}_{4} \mathrm{Y}$ are given in norm litre per kilogramme $\left(\mathrm{L}_{\mathrm{N}} \mathrm{kg} \mathrm{DM}^{-1}\right)$ and are corrected of volatile fatty acids (VFA). 


\section{Heating generation potential (HGP)}

The potential of a digested substrate to generate heat as a uniform energetic measure was based on the mean calorimetric value of a normed volume of methane $\left(\mathrm{L}_{\mathrm{N}}\right.$ $\mathrm{CH}_{4}$ ) following standard emphasis [42]:

$$
\mathrm{HGP}=9.969\left(\mathrm{~L}_{\mathrm{N}} \mathrm{CH}_{4} \mathrm{~kg}^{-1}\right)
$$

HGP is given in $\mathrm{kWh} \mathrm{kg} \mathrm{oDM}^{-1}$.

\section{Data analysis}

Data records of interest were first tested for normal distribution using the Shapiro-Wilk test and transformed if necessary. Differences in substrate characteristics and energy yields between conversion techniques were analysed by ANOVA followed by post hoc test of the means (Tukey HSD, $p<0.05$ ). Scripts using the $\mathrm{R}$ environment, version 3.3.2, performed all statistical analysis [43].

\section{Results}

Biochemical characteristics of the initial substrates

Due to the different test application cycles and site backgrounds, the soft rush biomass used for the individual conversion pathways was not identical. Table 2 gives an overview of the biochemical composition of the rush biomasses depending on its use. The dry matter (DM) content of the solid-state application $(40.1 \%)$ is due to the preceding wilting phase as part of silage preparation. The untreated ("fresh") biomass for the wet fermentation experiment was even higher in DM (45.5\%) because of the higher physiological development stage of the rushes at the time of sampling and a further water release during transport to the lab. The rush growths for the combustion tests were technically dried to ensure good combustion suitability.

The two manually harvested biomasses (that for wet fermentation and combustion) showed no soil adhesions and had very low crude ash contents. The combined consideration of crude fibre (CF) and crude protein (CP) content served as a proxy for assessing the plant development stage. The high CF and low CP content of the biomass intended for wet fermentation indicated an advanced degree of ripeness compared to the biomass for solid-state fermentation. The physiologically younger but ensiled biomass intended for solid-state fermentation showed even a higher content of enzyme-insoluble organic substance (EULOS) as a more lignified and thus more recalcitrant fraction in bio-digestion processes.

\section{Wet fermentation batch tests}

The cumulative development of gas formation from the tested soft rush substrate is shown in Fig. 2. The measured values are shown there in standard litres per unit of volatile solid in order to achieve the best possible comparability with other measurement results.

From about day 5 onwards, the gas formation processes in the batch vessels have stabilised. The further development of gas formation took place quasi-linearly over a period of approx. 25 days (Fig. 2a). Remarkably, a slight increase in gas formation was observed from the 30 th to the termination of the experiment on the 35th incubation day. The described trend of gas formation hardly varied between the three repetitions. The dynamics of methane formation (Fig. 2b) was only slightly behind the total biogas formation in the first week, but followed the same trend thereafter.

The summarised results of the standardised batch test according to the VDI Guideline 4630 are presented in Table 3. We added up the daily-determined gas production and subtracted the proportion of gas from the inoculation sludge (control) from the yield of the substrate to be examined. It should be noted that the presented values refer to the entire test duration of 35 days. This is important because such batch tests with higher-energy substrates are often run with a restricted test duration of 30 days.

After 35 days of digestion, an average of $172 \mathrm{~L}_{\mathrm{N}} \mathrm{kg}^{-1}$ FM or $399 \mathrm{~L}_{\mathrm{N}} \mathrm{kg}^{-1}$ oDM biogas was obtained from the substrate examined (Table 3). Table 3 also shows the proportion of methane in the biogas volumes formed, which is important for the quality of the gas produced and thus its later use.

Table 2 Biochemical characteristics of the conditioned rush biomass prior to their use in different energy conversion routes (means from two laboratory repetitions with standard deviations in parentheses)

\begin{tabular}{|c|c|c|c|c|c|c|c|}
\hline $\begin{array}{l}\text { Substrate condition and } \\
\text { application purpose }\end{array}$ & $\begin{array}{l}\text { Dry matter content } \\
(\% \text { FM) }\end{array}$ & $\begin{array}{l}\text { Crude ash } \\
\text { (\% DM) }\end{array}$ & $\begin{array}{l}\mathrm{C} \\
(\% \mathrm{DM})\end{array}$ & $\begin{array}{l}\mathrm{S} \\
(\% \mathrm{DM})\end{array}$ & $\begin{array}{l}\text { Enzyme-insoluble organic } \\
\left.\text { substance (EULOS } \mathrm{g} \mathrm{kg}^{-1} \mathrm{DM}\right)\end{array}$ & $\begin{array}{l}\text { Crude fibre } \\
\text { (\% DM) }\end{array}$ & $\begin{array}{l}\text { Crude protein } \\
(\% \text { DM) }\end{array}$ \\
\hline $\begin{array}{l}\text { Silage for solid-state } \\
\text { fermentation }\end{array}$ & $40.14[2.17]$ & $5.46[0.18]$ & $44.17[0.02]$ & $0.22[0.003]$ & $489.80[63.01]$ & $29.72[2.74]$ & $11.94[1.42]$ \\
\hline $\begin{array}{l}\text { Fresh biomass for wet } \\
\text { fermentation }\end{array}$ & $45.53[0.14]$ & $3.03[0.01]$ & $45.12[0.01]$ & 0.18 [0.002] & $456.97[14.32]$ & $33.43[0.25]$ & $7.86[0.01]$ \\
\hline $\begin{array}{l}\text { Dried biomass for } \\
\text { combustion }\end{array}$ & 97.93 [0.08] & $2.92[0.12]$ & na & na & na & na & na \\
\hline
\end{tabular}

na not analysed 


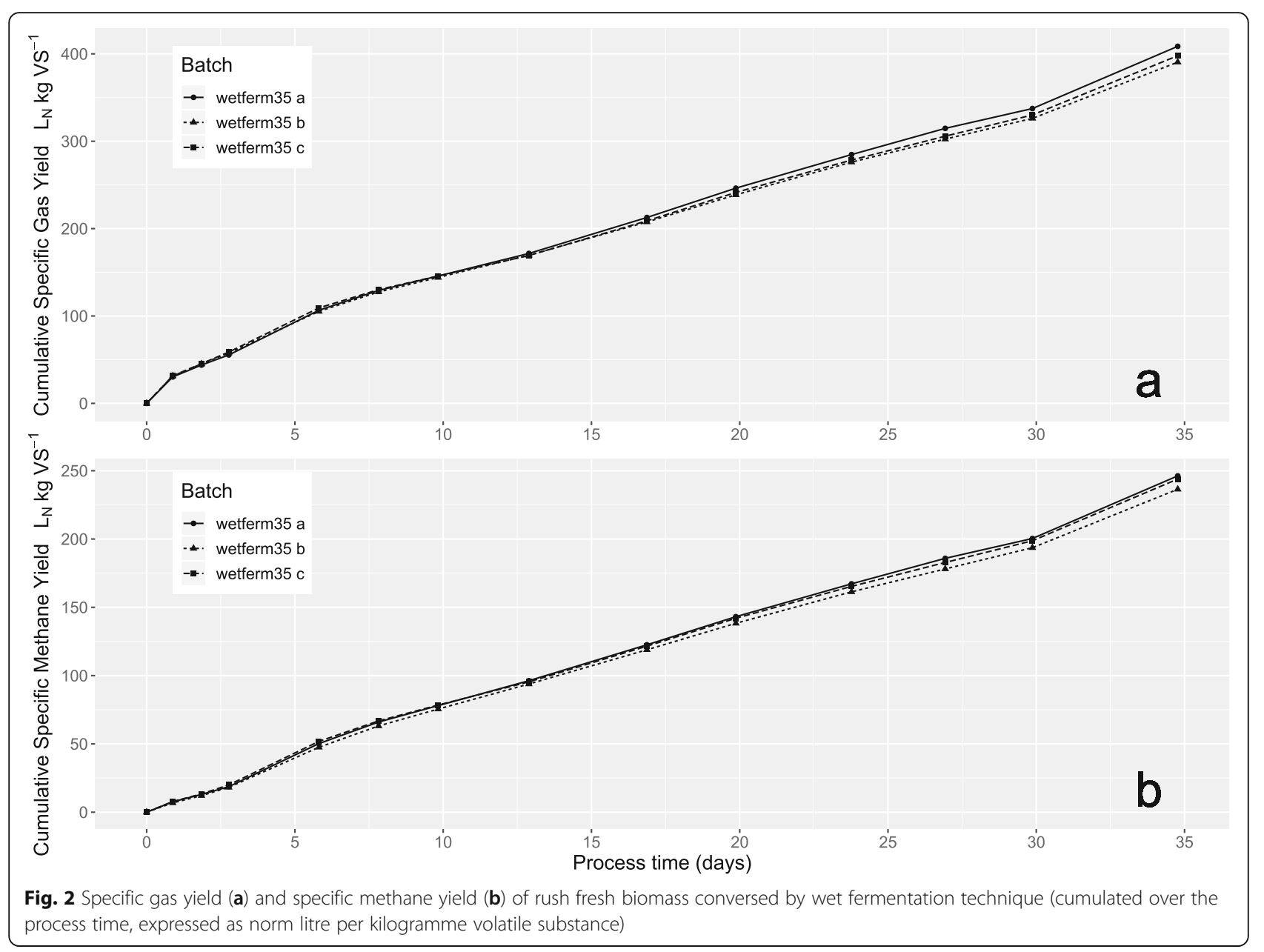

\section{Solid-state fermentation tests}

The cumulative gas formation from ensiled soft rush biomass in a solid-state fermentation set up is shown in Fig. 2. In the first two repetitions, which were stopped as planned on the 43rd day, a progressive trend of gas formation rates could be observed. Therefore, the next two repetitions were fermented over a longer period of 61 days. It is noteworthy that the gas formation curves did not flatten even at the end of the extended fermentation time.

It is apparent that the single replications differed in their fermentation yields and that these variations increased as the experiment progressed. Methane formation (Fig. 3b) lagged behind biogas formation in the first 2 weeks after loading and then developed adequately for gasification as a whole. This led to slowly increasing methane concentrations, which only reached values above $50 \%$ after 14 days. The $\mathrm{pH}$ values (6.4-8.2) and FOS/ TAC ratios $(0.02-0.04)$, however, were within the normal range. Loading rates varied between replications in a range of 45.02 to $52.25 \mathrm{~g}$ oDM per litre. Summarised results of the solid-state fermentation tests are given in Table 4.

Table 3 Final specific biogas $(\mathrm{BG})$ and methane $\left(\mathrm{CH}_{4}\right)$ yields of pure soft rush (Juncus effusus) after 35 days of wet co-digestion. Gas yields are given in standard norm litres $\left(L_{N}\right)$ per kilogramme of fresh matter $(F M)$ and per kilogramme of ash excluded organic dry matter (oDM)

\begin{tabular}{|c|c|c|c|c|c|}
\hline Substrate (replication) & $\mathrm{L}_{\mathrm{N}} \mathrm{BG} \mathrm{kg} \mathrm{FM}^{-1}$ & $\mathrm{~L}_{\mathrm{N}} \mathrm{BG} \mathrm{kg}_{\mathrm{oDM}} \mathrm{DM}^{-1}$ & $\mathrm{~L}_{\mathrm{N}} \mathrm{CH}_{4} \mathrm{~kg} \mathrm{FM}^{-1}$ & $\mathrm{~L}_{\mathrm{N}} \mathrm{CH}_{4} \mathrm{~kg} \mathrm{oDM}^{-1}$ & $\mathrm{CH}_{4}$ Vol. $\%$ \\
\hline Juncus effusus (a) & 176.65 & 408.64 & 106.44 & 246.23 & 60.3 \\
\hline Juncus effusus (b) & 168.81 & 390.51 & 102.20 & 236.43 & 60.5 \\
\hline Juncus effusus (c) & 172.00 & 397.89 & 105.44 & 243.92 & 61.3 \\
\hline Mean (sd) & $172.48(3.22)$ & $399.02(7.44)$ & $104.69(1.81)$ & $242.19(4.18)$ & $60.7(0.43)$ \\
\hline
\end{tabular}




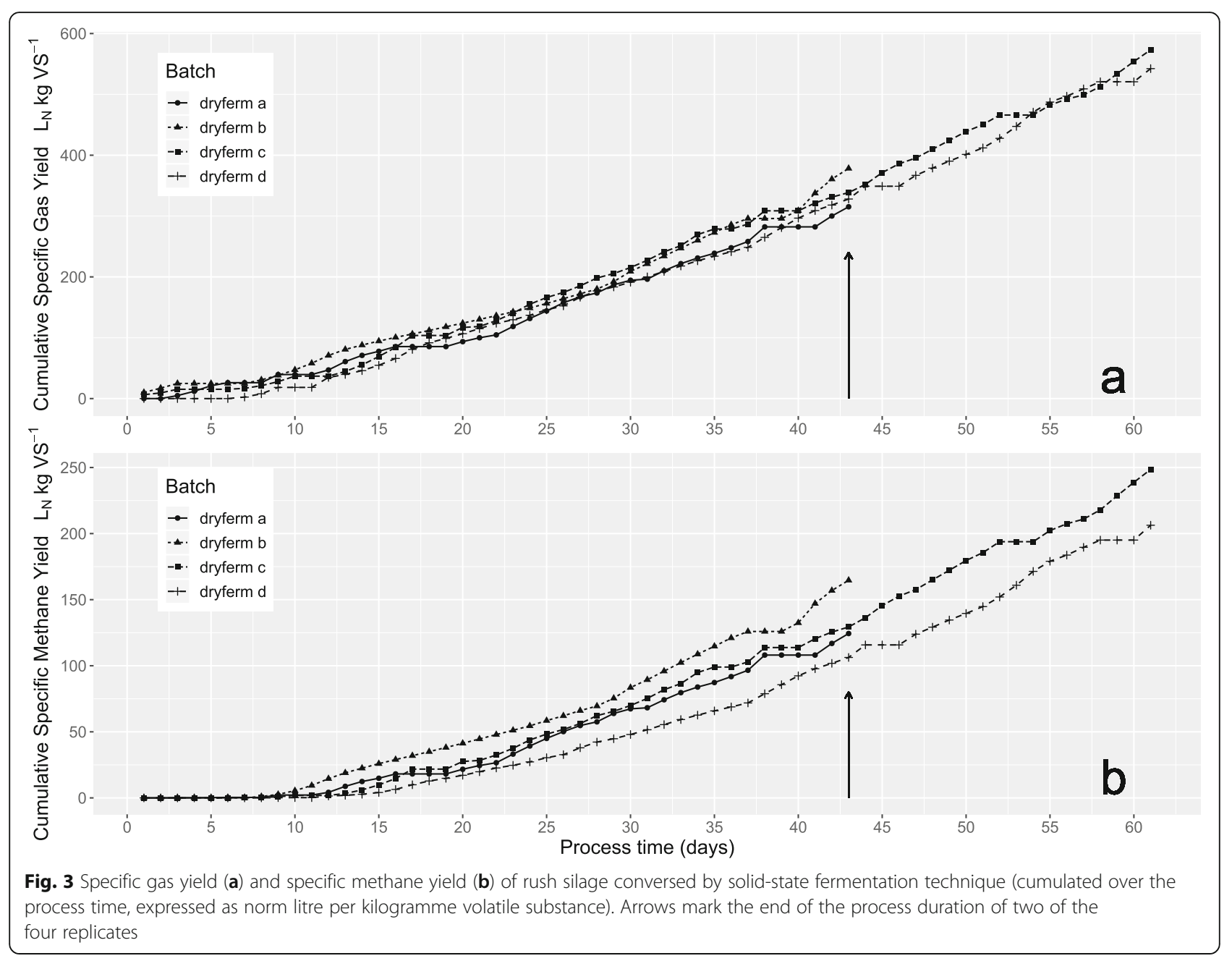

\section{Combustion tests}

The results of the thermo-gravimetrical and calorimetric analysis (TGA) are shown in Table 5. In order to allow the readers a comprehensive comparison with other biomass-based fuels and corresponding data, both gross caloric values and calorific values were presented with different reference bases.

The material used for the TGA was advertised by hand and oven-dried to get reliable gross caloric values. On the other hand, these procedures resulted in artificial harvest conditions and a composition of the biomass that does not correspond to that produced under practical conditions. For this reason, plausible assumptions regarding crude ash content $(8 \% \mathrm{DM})$ and residual moisture $(15 \% \mathrm{DM})$ have been made in a further step and the net calorific value of the rush biomass based on them $\left(H_{i}\right)$ has been recalculated $\left(15.06 \mathrm{MJ} \mathrm{kg} \mathrm{FM}_{\mathrm{w} 15}{ }^{-1}\right)$. We present this calculation together with compositional data

Table 4 Final specific biogas (BG) and methane $\left(\mathrm{CH}_{4}\right)$ yields of silage made from pure soft rush (Juncus effusus) as a single solidstate fermentation substrate. Gas yields are given in standard norm litres $\left(L_{N}\right)$ per kilogramme of fresh matter (FM) and per kilogramme of ash excluded organic dry matter (oDM)

\begin{tabular}{|c|c|c|c|c|c|}
\hline Substrate (replication) & Resident time & $L_{N} B G k g ~ F M^{-1}$ & $L_{N} B G$ kg oDM ${ }^{-1}$ & $\mathrm{~L}_{\mathrm{N}} \mathrm{CH}_{4} \mathrm{~kg} \mathrm{FM}^{-1}$ & $\mathrm{~L}_{\mathrm{N}} \mathrm{CH}_{4} \mathrm{~kg} \mathrm{oDM}^{-1}$ \\
\hline Juncus effusus (a) & 43 & 119.98 & 315.23 & 47.34 & 124.38 \\
\hline Juncus effusus (b) & 43 & 143.99 & 378.30 & 62.67 & 164.66 \\
\hline Juncus effusus (c) & 61 & 218.17 & 573.19 & 94.60 & 248.55 \\
\hline Juncus effusus (d) & 61 & 206.42 & 542.34 & 78.53 & 206.31 \\
\hline Mean (sd) & 43 & 131.99 (12.01) & $346.77(31.54)$ & $55.01(7.66)$ & $144.52(20.14)$ \\
\hline Mean (sd) & 61 & $212.30(5.88)$ & $557.77(15.43)$ & $86.57(8.04)$ & $227.43(21.12)$ \\
\hline
\end{tabular}


Table 5 Gross calorific values $\left(H_{\mathrm{s}}\right)$ and net calorific values $\left(\mathrm{H}_{\mathrm{i}}\right)$ of dried soft rush (Juncus effusus) biomass with different reference values regarding water and ash contents. Results of the thermo-gravimetrical and calorimetric analysis (TGA)

\begin{tabular}{llllllllll}
\hline Fuel substrate & w\% & DM\% & CA\% & $H_{s}$ & $H_{\text {s(wf) }}$ & $H_{\text {s(waf) }}$ & $H_{i}$ & $H_{\text {(wf) }}$ & $H_{\text {(waf) }}$ \\
\hline Juncus effusus (a) & 2.15 & 97.85 & 3.03 & 18.276 & 18.624 & 19.150 & 18.263 & 18.610 & 19.136 \\
Juncus effusus (b) & 1.96 & 98.04 & 3.01 & 18.276 & 18.667 & 19.199 & 18.263 & 18.654 & 19.185 \\
Juncus effusus (c) & 2.10 & 97.90 & 2.99 & 18.541 & 18.949 & 19.485 & 18.528 & 18.936 & 19.471 \\
Mean (sd) & $2.07(0.08)$ & $97.93(0.08)$ & $3.01(0.02)$ & $18.364(0.12)$ & $18.747(0.14)$ & $19.278(0.15)$ & $18.351(0.12)$ & $18.733(0.14)$ & $19.264(0.15)$ \\
\hline
\end{tabular}

and calorific value of rush biomass compared to other common biomass-based fuels in Table 6. It should be noted that all data of the reference fuels were also obtained in the same laboratory with the same methods.

The net calorific values of the rushes even proved to be superior to those of the most common herbaceous biomasses used as fuel. This was mainly due to the high values of volatile matter (Table 6).

\section{Comparison of conversion routes}

Finally, we evaluated the tested conversion paths according to the degree of energy recovery achieved. In a first step, we compared the two processes of wet fermentation and solid-state fermentation based on the same basic principle of methanation. We used specific methane yield per weight unit of volatile solid as a measure to compare the two fermentation techniques (see Fig. 4). The most common and known high-yielding substrate, maize silage, was included in the comparison as a reference standard. The amount of the specific biogas yield potential of the maize substrate according to Weißbach [41] was exactly in the range of our wet fermentation measurements. However, this did not apply to the fermented rush biomass. The distance between the mean values (bars) and the estimates of the methane potential based on the composition of the substrates (yellow dots) can be regarded as a measure of conversion efficiency.

With a 35-day residence time in the process of wet fermentation, the methane formation potential of the soft rush could be exploited to about $90 \%$. The solid fermentation process requires a significantly longer residence time to reach this exploitation range. After 43 days, only $58 \%$ of the expected methane potential of the pure rush silage could be harvested with the solid-state lab equipment we used.
In a second step, the combustion variant is included in the comparison of the conversion paths by converting the specific methane yield of the fermentation variants into their heating generation potential. The results of these calculations are shown in Fig. 5. The ranking of the methanisation variants is the same as that of the specific methane yields, since this is merely a conversion with a constant factor (see Equation 6 in the methods chapter) towards the heating value.

The $H_{i}$-value of $5.39 \mathrm{kWh} \mathrm{kg} \mathrm{oDM}^{-1}$ presented as the combustion bar in Fig. 5 is not far away from the gross calorific value and thus represents a kind of biomassinherent energy maximum. In this sense, the diagram shows that about half of the material energy content of the rush biomass could be tapped by methanation. In other words: half of the energy was still in the digestate.

\section{Discussion}

General features of rush biomass as an energy substrate Worthwhile areas with rush-infested or even dominated wet grassland can be found in Northern, Western and Central Europe, especially in the large fen lowlands with extensive use and nature conservation constrains, but also on blanket bogs. In many wetlands of the world, tall growing representatives of the genus Juncus predominate, perhaps the best known being the Everglades. From a purely quantitative point of view, the extent of retention and phytoremediation areas based on rush vegetation is still small, but is attracting increasing attention, especially in Asia.

The composition of each plant, including the soft rush, changes in the course of phenological development. From an economic point of view, however, early developmental stages are irrelevant for biomass production because they are associated with insufficient harvest

Table 6 Composition and net calorific values of biomass from rushes compared to other common biomass-based fuels

\begin{tabular}{|c|c|c|c|c|c|c|c|}
\hline \multicolumn{2}{|c|}{ Kind of biomass } & \multirow{2}{*}{$\begin{array}{l}\text { Crude ash (\% DM) } \\
3.01(0.02)\end{array}$} & \multirow{2}{*}{$\begin{array}{l}\text { Volatile matter (\% oDM) } \\
80.59\end{array}$} & \multirow{2}{*}{$\frac{\text { C-fix (\% oDM) }}{19.43(1.95)}$} & \multirow{2}{*}{$\frac{H_{i(w f)}\left(\mathrm{MJ} \mathrm{kg} \mathrm{DM}^{-1}\right)}{18.73(0.14)[17.22]^{\mathrm{a}}}$} & \multirow{2}{*}{$\frac{H_{i}\left(\mathrm{MJ} \mathrm{kg} \mathrm{FM}_{\mathrm{w} 15}{ }^{-1}\right)}{15.06}$} & \multirow{2}{*}{$\frac{H_{i}\left(\mathrm{kWh} \mathrm{kg} \mathrm{FM} M_{\mathrm{w} 15}{ }^{-1}\right)}{4.18}$} \\
\hline Herbaceous & Soft rush & & & & & & \\
\hline & Hay & $6.00(0.26)$ & 79.71 & $20.29(0.23)$ & $16.59(0.19)$ & 14.10 & 3.92 \\
\hline & Straw & $8.35(0.09)$ & 79.44 & $20.56(0.35)$ & $16.60(0.01)$ & 14.11 & 3.92 \\
\hline \multirow[t]{2}{*}{ Wood } & Pine & $0.24(0.05)$ & 82.23 & $17.77(0.27)$ & $20.07(0.19)$ & 15.96 & 4.43 \\
\hline & Oak & $0.34(0.13)$ & 78.87 & $21.13(0.77)$ & $17.56(0.23)$ & 14.92 & 4.15 \\
\hline
\end{tabular}

assumption: crude ash content of $8 \% \mathrm{DM}$ as expected under harvest conditions in practice 


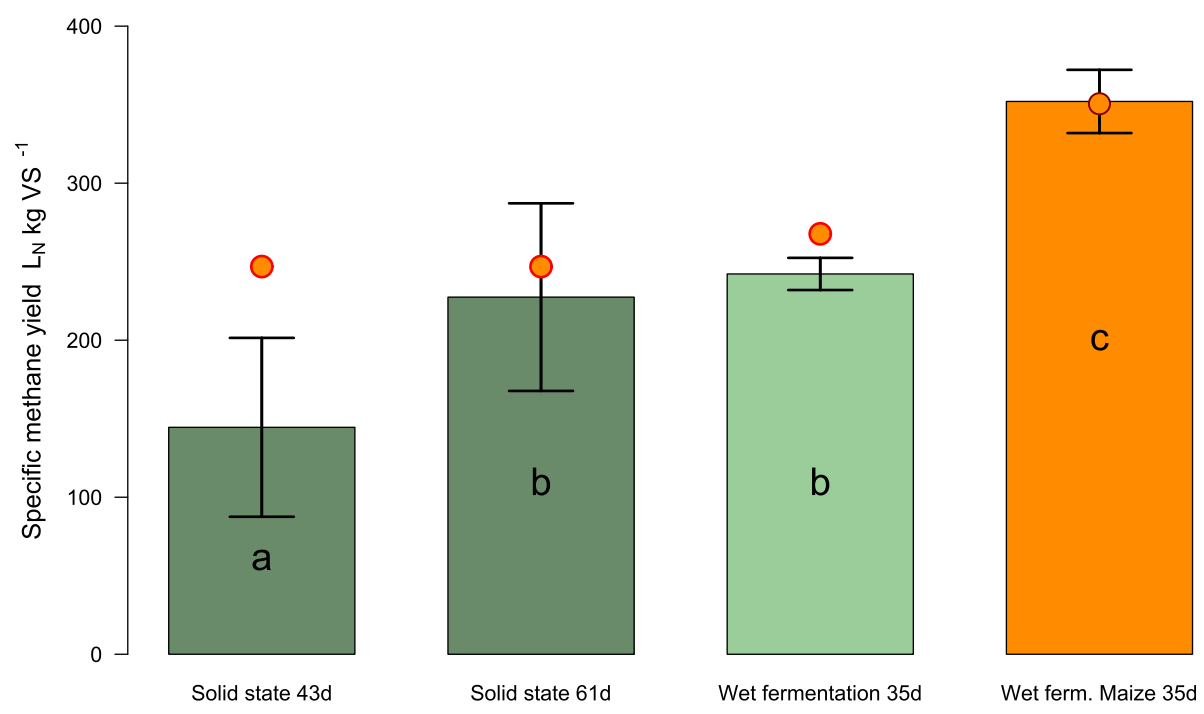

Fig. 4 Mean specific methane yield $\left(L_{N} \mathrm{~kg} \mathrm{VS}^{-1}\right)$ of different fermented soft rush biomass compared with maize as a reference co-substrate. Different letters indicate significant differences of the means (Tukey's HSD, $p<0.05$ ). Error bars indicate standard deviations of the means. Dots mark the amount of specific biogas yield potential according to Weißbach [41]

yields [44]. In addition, wetlands where rush-dominated stands develop have a limited trafficability in spring when groundwater levels are high [45]. Therefore, the description of the composition of the rush biomass can be limited to developed plant stands of rushes and thus claim a certain general validity.

Our results have shown that harvest-worthy rushdominated stands are characterised by relatively high $\mathrm{C}$ contents, low $\mathrm{N}$ contents and slightly increased $\mathrm{S}$ contents compared to other herbaceous plants. For the two methanation processes, the specific $\mathrm{C}$-containing organic compounds are much more relevant than the $\mathrm{C}$ content $[41,46]$. We found high cell wall proportions and relatively few soluble carbohydrates, whereby the latter are largely used up in ensiling. Rush biomass has a high EULOS content indicating limited success of microbiological depolymerisation of these cell walls during digestion. According to Weißbach [47], enzyme-insoluble organic substance correlates negatively with the methane yield. Although the lignin content was not explicitly determined in this study, the constellation of high cell wall contents and limited enzymatic solubility indicates a high degree of lignification of the older plant parts. While this content pattern does not promise optimal conditions for methanisation, it suggests a high calorific value when used as a solid biofuel.

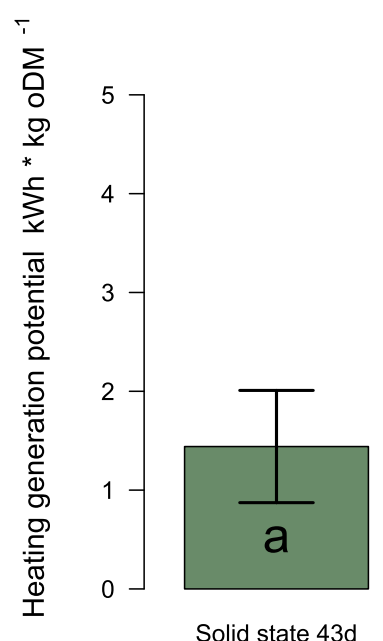

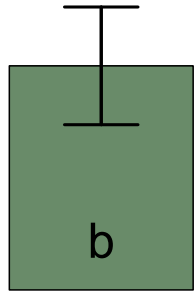

Solid state $61 \mathrm{~d}$

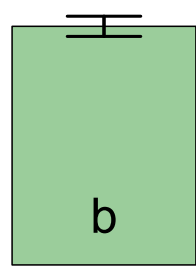

Wet fermentation 35d

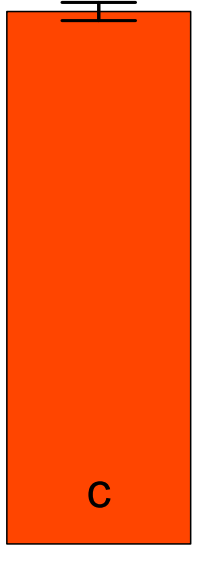

Combustion

Fig. 5 Comparison of the heating generation potential $\left(\mathrm{kWh} \mathrm{kg} \mathrm{DM}^{-1}\right)$ of soft rush biomass in different conversion routes. Different letters indicate significant differences of the means (Tukey's HSD, $p<0.05$ ). Error bars indicate standard deviations of the means 
For a successful application of rush biomass in incineration plants, however, not only the calorimetric energy content but also the dry matter content and the mineral composition plays a pivot role. One difficulty in the field drying of rushes for combustion purpose is the wet conditions of their preferred habitats. Dry periods at late summer must therefore be consistently exploited for rush hay preparation. Where the target dry matter content of $80 \%$ cannot be achieved by field drying, precautions must be taken for subsequent drying under rain shelter conditions. According to Joseph et al. [34], mineral composition of wet grassland vegetation dominated by rushes does not differ significantly from that of other extensive grassland growths. However, this may be not true in the case of origins from coastal [48] or retentional $[17,49]$ areas. For example, Juncus gerardii as a halophytic salt marsh rush contains significantly higher contents of $\mathrm{Na}$ and $\mathrm{Cl}$ than Juncus effusus in inland areas [50]. When recovering rushes from phytoremediation applications [16], it must be assumed that the phosphorus content of the rush biomass exceeds that of natural populations $[13,18]$ and that heavy metals and organic complexing agents are also present [17], whose behaviour in the individual conversion techniques is largely unknown. Further research is needed on this issue.

Another special feature of rush biomass is its physical structure. Rush tillers are characterised by aerenchyma which allow gas diffusion through the tissues [51]. This property could, even in chopped condition, have an influence on certain utilisation processes such as the oxygen supply during combustion or the methane removal during anaerobic fermentation. These hitherto unexplored aspects would be worth a closer look.

While the majority of semi-natural grassland areas infested with rushes also contain certain proportions of grasses and herbs and thus represent mixed biomass stands, in the case of retention areas and conceivable paludicultures, these are pure stands. For the latter, the results of this study can be used directly. In the case of mixed biomasses, further investigations with targeted variation of the accompanying flora are necessary in order to be able to reliably estimate the energetic exploitation potential.

\section{Evaluation of rush biomass as substrate in special conversion routes Wet fermentation}

For our knowledge, we presented first results of specific biogas yield of biomass from rushes as substrate in wet fermentation process here. With a specific methane yield of $242 \mathrm{~L}_{\mathrm{N}} \mathrm{kg}^{-1}$ oDM, a level was achieved which corresponds to that of other substrates from landscape management growths $[52,53]$. Nearly $90 \%$ of the expected methane potential of the soft rush biomass could be tapped in 35 days retention time. Since the methane formation curve did not flatten out even towards the end of the experiment, we assume that the wet fermentation process is able to almost completely tap the methane formation potential. However, the residence time in continuous-flow plants, which dominate in practice, will probably not be sufficient to achieve the maximum energy yield. In addition, the wet fermentation plants must be designed in such a way that floating of the aerenchyma-containing material in the premix pit is prevented. A short chop length, which is highly recommended for rush biomass, also contributes to avoid this loading problem. It cannot be assumed that the operating concept of a wet fermentation biogas plant is based on rush biomass as the main substrate. Nevertheless, the use of rush biomass as a component of a co-substrate mixture seems practicable.

\section{Solid-state fermentation}

Solid-state fermentation techniques are not widely used in farm practice, but occur in waste management. An advantage of these plants for lignocelluloserich biomasses is the longer residence time [54] and the associated possibility of accelerating microbial cellulolytic processes [55]. Therefore, hopes for an economic exploitation of landscape management biomasses rest on this conversion technique. In our study, these hopes could not be fulfilled by using ensiled rush biomass as the sole substrate. The obvious reason was the delayed formation of methane in the initial phase of fermentation, a problem that other experimenters using solid-state techniques also reported $[56,57]$. As reasons for the restrained methane formation after loading, hyperacidity (VFA overload) [54] and too high ammonium concentrations [58] are listed. We can exclude both causes for our experiments. It is likely that our test facility will require an optimisation of the sprinkler technology in the startup phase as well as an inoculum that originated from cultures of the test substrate. Despite these limitations, we still see potential for increasing conversion efficiency in the solid-state fermentation process. For example, the percolation frequency can be increased. Also, the use of rush biomass as a pure substrate does not appear to be very useful. In previous investigations on the same experimental set-up, the advantages of rush biomass as a mixing partner for grassland crops could be demonstrated [59]. Therefore, in contrast to the results of the wet fermentation experiment, we consider our measurement results for the solid-state conversion of the rush biomass to be rather lower guide values, which could be exceeded in practice. 


\section{Combustion}

In the absence of further data on the calorific value of rushes, comparison with other biomass-based fuels helps to classify the results. We found that the net calorific value of dried biomass from soft rush exceeds that of the most common herbaceous solid fuels, straw and hay. This finding is mainly due to the relatively high content of volatile matter in the rush biomass, while the fixed carbon content was similar to that of the herbaceous reference fuels. A high proportion of volatile matter in turn makes the rush biomass also interesting for pyrolysis processes, which we have not considered here. When evaluating the heating values of rush biomass, it must be taken into account that the raw ash contents are unusually low due to manual harvesting. But even assuming a more realistic raw ash content of $8 \%$ and a residual moisture content of $15 \%$ of the fuel, the net calorific value of $15.06 \mathrm{MJ} \mathrm{kg} \mathrm{FM}_{\mathrm{w} 15}{ }^{-1}$ is still attractive for thermal conversion. While the calorific value shows a potential, its implementation in terms of incineration technology remains a challenge. Profound knowledge of the chemical composition and physical properties of the ashes is necessary for optimising combustion process [60]. The composition of the ash in turn depends on the mineral pattern [61], which was not fully investigated in the study presented.

\section{Benefits and prospects of using rush biomass for bioenergy production}

Biochemical properties and realised energy yields of biomasses from rush dominated wetland stands do not show rushes as excellent energy plants, which is why there are no efforts to cultivate them for energetic purposes actually. However, this is not even necessary, as rush biomass is produced anyway in the course of landscape and nature conservation management. If we take the nutrient retention areas additionally into account, which also require the removal of biomass for nutrient export purposes, we obtain a promising energy reservoir free of opportunity costs. Seen in this light, the use of such kind of biomass integrated into an overall social concept can be regarded as an example of modern land use policy [62]. From a societal point of view, the main advantage of the production of bioenergy from rush-dominated wetland biomass is its potential to combine renewable energy policies and landscape conservation goals while avoiding competition with food and forage production.

Nevertheless, the exploitation of these potentials is not easy, especially because of the scattered location of the rush infested wetland sites in a given landscape context. It cannot be assumed that the operating concept of a bioenergy plant is based on rush biomass as main substrate. What we have been able to show with our results is that it is possible to use various conversion routes with rush biomass as a substrate. For this purpose, the advantages and disadvantages of the specific material properties of the rush biomass for the respective conversion path must be known and considered accordingly in the process design. This study has made a contribution to this.

\section{Conclusions}

In this paper, we analysed the use of biomass from soft rush (Juncus effusus L.) in three different conversion routes. We used largely standardised and thus comparable methods for the conversion paths of wet fermentation and combustion as well as a less common technique for determining substrate suitability in the solid-state fermentation technique. According to our results and from a pure calorimetric point of view, the energy potential of rush growths at a developed physiological stage can best be exploited by combustion, whereas biodigestive approaches are at a disadvantage from the outset due to the high proportion of poorly degradable cell wall structures. Nevertheless, fermentation techniques have also been able to achieve energy yields that are not below those of other waste biomasses from landscape management. In addition, the high proportion of recalcitrant $\mathrm{C}$ compounds in the fermentation residues can also be an advantage in supplying agricultural soils with a stable $\mathrm{C}$ source. This kind of $\mathrm{C}$ fixation may also be beneficial to prevent $\mathrm{CO}_{2}$ losses and thus could act as a further contribution of a climate-friendly sustainable energy policy besides reducing greenhouse gas emissions generated from competing fossil fuels. Low costs for substrate production make energetic utilisation of rush stands an interesting alternative, if short distances between fields and biomass conversion plant can be realised. In Germany, the probability of short transport distances between wetlands with rush dominated stands and existing energy conversion techniques is much greater for biogas plants than for incineration plants. In order to increase the transportability of rushes as solid fuel, the biomass would have to be pelleted or briquetted, which causes additional costs. The preferability of such processed solid biofuels depends on the cost development in the field of fossil fuel carriers.

Solid-state fermentation is particularly suitable if the use of biomass from landscape management in a larger wetland complex is to be integrated into an ecological land use concept including extensive animal farming with farmyard manure as a further solid substrate. This technology still has development potential, but must be built cost-effectively in order to be economically viable. The current suppliers of technically mature plants do not meet this economical requirement. Finally, besides the size of the rush dominated area, and the distribution of these areas in the landscape, the investment costs and the subsidies for the conversion plant play a pivotal role in the selection of the preferred conversion process. 


\section{Abbreviations}

BG: Biogas; BGY: Biogas yield; C: Carbon; CA: Crude ash; CF: Crude fibre; Cfix: Proportion of solid fuel; $\mathrm{CH}_{4}$ : Methane; $\mathrm{CH}_{4} \mathrm{Y}$ : Methane yield; $\mathrm{CP}$ : Crude protein; DM: Dry matter; EULOS: Enzyme-insoluble organic substance; FM: Fresh matter; FOS: Volatile organic acids; HGP: Heat generation potential; $H_{s}$ : Gross caloric value; $H_{i}$ : Caloric value; kWh: Kilowatt hour; $L_{N}$ : Standard norm litre; oDM: Ash excluded organic dry matter; S: Sulphur; TAC: Total alkaline carbonates (buffer capacity); TGA: Thermo-gravimetrical analysis; VFA: Volatile fatty acids; VS: Volatile solids (fermentable organic matter); w\%: Water content; wf: Water free; waf: Water and ash free

\section{Acknowledgements}

We dedicate this contribution to the initiator of this special issues 'Sustainable use of aquatic macrophytes for the production of bioenergy', Prof. Andreas Zehnsdorf, who encouraged us to make this contribution and unfortunately died far too early. We are grateful to Kristof Habermann who participated in the wet fermentation part of our investigation. Moreover, we thank the reviewers of this journal, who provided us with critical and thorough feedback to improve the quality of this contribution.

\section{Authors' contributions}

JM and CJ contributed to the conception and the design of the study. DW organised and administrated the wet fermentation experiments and did the efficiency calculations. CJ was responsible for the solid-state and combustion measurements. JM wrote the first draft of the manuscript. CJ and DW supplemented and improved the manuscript. JM performed the statistical analysis in coordination with CJ and DW. All authors contributed to manuscript revision and read and approved the submitted version.

\section{Funding}

One measurement run of solid fermentation was taken from material generated in the project 'Restoration of species-rich moor grassland through a sustainable agricultural use with special regard on the soft rush problem', funded by the German Federal Foundation for the Environment DBU (Deutsche Bundesstiftung Umwelt, grant number: 23063/01). All other data sets were obtained within the framework of student graduation theses without external financial support.

\section{Availability of data and materials}

All relevant data is contained within the manuscript. In addition, raw data from processed data will be made available by the authors, without undue reservation, to any qualified researcher on request.

\section{Ethics approval and consent to participate}

Not applicable.

\section{Consent for publication}

All participants consented the confidential publication of their contributions in this study.

\section{Competing interests}

The authors declare that they have no competing interests.

\section{Author details}

${ }^{1}$ Grassland and Forage Science, Faculty of Agricultural and Environmental Sciences, University of Rostock, Justus-von-Liebig-Weg 6, 18059 Rostock, Germany. ${ }^{2}$ Biotechnology and Process Engineering, Faculty of Agricultural and Environmental Sciences, University of Rostock, Justus-von-Liebig-Weg 6, 18059 Rostock, Germany.

Received: 2 January 2020 Accepted: 24 June 2020 Published online: 23 July 2020

\section{References}

1. Harriman NA, Redmond D (1976) Somatic chromosome numbers for some north American species of Juncus L. Rhodora 78(816):727-738

2. Snogerup S (1993) A revision of Juncus subgen. Juncus (Juncaceae). Willdenowia 23(1/2):23-73

3. Hurd EG, Goodrich S, Shaw NL (1994) Field quide to intermountain rushes. General Technical Report INT-306, vol 306, Ogden, UT
4. Wetzel RG, Howe MJ (1999) High production in a herbaceous perennial plant achieved by continuous growth and synchronized population dynamics. Aquat Bot 64(2):111-129. https://doi.org/10.1016/S03043770(99)00013-3

5. Ervin GN, Wetzel RG (2002) Influence of a dominant macrophyte, Juncus effusus, on wetland plant species richness, diversity, and community composition. Oecologia 130(4):626-636

6. Boughton EH, Quintana-Ascencio PF, Bohlen PJ (2011) Refuge effects of Juncus effusus in grazed, subtropical wetland plant communities. Plant Ecol 212(3):451-460. https://doi.org/10.1007/s11258-010-9836-4

7. Yoon J, Kim H, Nam JM et al (2011) Optimal environmental range for Juncus effusus, an important plant species in an endangered insect species (Nannopya pygmaea) habitat in Korea. J Ecol Environ 34(2):223-235. https:// doi.org/10.5141/JEFB.2011.024

8. Kaczmarek-Derda W, Folkestad J, Helgheim M et al (2014) Influence of cutting time and stubble height on regrowth capacity of Juncus effusus and Juncus conglomeratus. Weed Res 54(6):603-613. https://doi.org/10. 1111/wre.12105

9. Cherrill A (1995) Infestation of improved grasslands by Juncus effusus L. in the catchment of the river Tyne, northern England: a field survey. Grass Forage Sci 50(1):85-91

10. Ervin GN (2005) Spatio-temporally variable effects of a dominant macrophyte on vascular plant neighbors. Wetlands 25(2):317-325

11. Smolders AJP, Lucassen ECHET, van der Alst M et al (2008) Decreasing the abundance of Juncus effusus on former agricultural lands with noncalcareous sandy soils: possible effects of liming and soil removal. Restor Ecol 16(2):240-248

12. der Welle V, Marlies EW, Niggebrugge K, Lamers LPM et al (2007) Differentia responses of the freshwater wetland species Juncus effusus $L$. and Caltha palustris L. to iron supply in sulfidic environments. Environ Poll (Barking, Essex : 1987) 147(1):222-230

13. Ennabili A, Ater M, Radoux M (1998) Biomass production and NPK retention in macrophytes from wetlands of the Tingitan peninsula. Aquat Bot 62(1): 45-56. https://doi.org/10.1016/S0304-3770(98)00075-8

14. Abel S, Couwenberg J, Dahms T et al (2013) The database of potential paludiculture plants (DPPP) and results for western Pomerania. Plant diversity and evolution 130:219-228

15. Coleman J, Hench K, Garbutt K et al (2001) Treatment of domestic wastewater by three plant species in constructed wetlands. Water Air Soil Pollut 128(3):283-295. https://doi.org/10.1023/A:1010336703606

16. Menon R, Holland MM (2013) Phosphorus retention in constructed wetlands vegetated with Juncus effusus, Carex lurida, and Dichanthelium acuminatum var. acuminatum. Water Air Soil Pollut 224:7. https://doi.org/10. 1007/s11270-013-1602-5

17. Syranidou E, Christofilopoulos S, Kalogerakis N (2017) Juncus spp.- - the helophyte for all (phyto)remediation purposes? New Biotechnol 38:43-55. https://doi.org/10.1016/j.nbt.2016.12.005

18. Tanner CC (1996) Plants for constructed wetland treatment systems - a comparison of the growth and nutrient uptake of eight emergent species. Ecol Eng 7(1):59-83. https://doi.org/10.1016/0925-8574(95)00066-6

19. Müller J (2001) Concept of nutrient management in preserve grassland areas. (German with English summary). Land Use and Development 42(6): 284-288

20. Nielsen AL, Hald AB (2010) Shortcut strategies to improve plant species richness after years of intensive management in moist grassland. Grassland Science in Europe 15:1052-1054

21. Robson B, Allcorn RI (2006) Rush cutting to create nesting patches for lapwings Vanellus vanellus and other waders, lower Lough Erne RSPB reserve, county Fermanagh, Northern Ireland. Conservation Evidence 3:81-83

22. Odeyinka SM, Hector BL, Ørskov ER (2006) Nutritive evaluation of some trees and browse species from Scotland. Eur J Sci Res 14(3):311-318

23. Oertel D (2007) Industrielle stoffliche Nutzung nachwachsender Rohstoffe (industrial use of renewable raw materials). Sachstandsbericht zum monitoring "Nachwachsende Rohstoffe" (status report on monitoring 'renewable raw materials'). In German. Arbeitsbericht, Berlin.

24. Cicek N, Lambert S, Venema HD et al (2006) Nutrient removal and bioenergy production from Netley-Libau marsh at Lake Winnipeg through annual biomass harvesting. Biomass Bioenergy 30(6):529-536. https://doi. org/10.1016/j.biombioe.2005.12.009

25. Rösch C. Skarka J, Raab K et al (2009) Energy production from grassland assessing the sustainability of different process chains under German 
conditions. Biomass Bioenergy 33(4):689-700. https://doi.org/10.1016/j. biombioe.2008.10.008

26. Bressan RA, Reddy MP, Chung SH et al (2011) Stress-adapted extremophiles provide energy without interference with food production. Food Security 3(1):93-105. https://doi.org/10.1007/s12571-011-0112-9

27. Wang Y-C, Ko C-H, Chang F-C et al (2011) Bioenergy production potential for aboveground biomass from a subtropical constructed wetland. Biomass Bioenergy 35(1):50-58. https://doi.org/10.1016/j.biombioe.2010.08.032

28. Melts I, Ivask M, Geetha M et al (2019) Combining bioenergy and nature conservation: an example in wetlands. Renew Sust Energ Rev 111:293-302. https://doi.org/10.1016/j.rser.2019.05.028

29. Saidur R, Abdelaziz EA, Demirbas A et al (2011) A review on biomass as a fuel for boilers. Renew Sust Energ Rev 15(5):2262-2289. https://doi.org/10. 1016/.j.rser.2011.02.015

30. Kaltschmitt M, Hartmann H, Hofbauer H (eds) (op. 2009) Energie aus Biomasse. Grundlagen, Techniken und Verfahren, 2., neu bearbeitete und erw. Aufl. Springer, Heidelberg

31. Scholwin F, Liebetrau J, Edelmann W et al. (op. 2009) Biogaserzeugung und -nutzung. In: Kaltschmitt M, Hartmann H, Hofbauer $\mathrm{H}$ (eds) Energie aus Biomasse. Grundlagen, Techniken und Verfahren, 2., neu bearbeitete und erw. Aufl. Springer, Heidelberg, pp 851-931

32. Corton J, Donnison IS, Patel M et al (2016) Expanding the biomass resource: sustainable oil production via fast pyrolysis of low input high diversity biomass and the potential integration of thermochemical and biological conversion routes. Appl Energy 177:852-862. https://doi.org/10.1016/j. apenergy.2016.05.088

33. Hensgen F, Bühle L, Donnison I et al (2012) Mineral concentrations in solid fuels from European semi-natural grasslands after hydrothermal conditioning and subsequent mechanical dehydration. Bioresour Technol 118:332-342. https://doi.org/10.1016/.biortech.2012.05.035

34. Joseph B, Hensgen F, Bühle L et al (2018) Solid fuel production from seminatural grassland biomass-results from a commercial-scale IFBB plant. Energies 11(11):3011. https://doi.org/10.3390/en11113011

35. Naumann C, Bassler R (2012) Die chemische Untersuchung von Futtermitteln, 3. Aufl. Handbuch der landwirtschaftlichen Versuchs- und Untersuchungsmethodik (VDLUFA-Methodenbuch), Verband Deutscher Landwirtschaftlicher Untersuchungs- und Forschungsanstalten. Hrsg. von Rolf Bassler ; Bd. 3,3. VDLUFA-Verl., Darmstadt

36. Verein Deutscher Ingenieure (VDI) (2016) Fermentation of organic materials - characterisation of the substrate, sampling, collection of material data, fermentation tests. Vergärung organischer Stoffe - Substratcharakterisierung, Probenahme, Stoffdatenerhebung, Gärversuche ICS 13.030.30, 27.190(VDI 4630). https://www.vdi.de/fileadmin/pages/vdi_de/redakteure/richtlinien/ inhaltsverzeichnisse/2385990.pdf

37. DIN Deutsches Institut für Normierung e.V. (2002) Prüfung fester Brennstoffe - Bestimmung des Wassergehaltes und der Analysenfeuchtigkeit (Testing of solid fuels - Determination of the water content and the moisture of analysis sample). in German(DIN 51718)

38. DIN Deutsches Institut für Normierung e.V. (2016) Biogene Festbrennstoffe - Bestimmung des Gehaltes an flüchtigen Bestandteilen (Solid biofuels - Determination of the content of volatile matter). in German(DIN EN ISO 18123). https://www.beuth.de/de/fachgebiete/ werkstoffe/fachdaten-einzelsicht-norm/wdc-beuth:din21:233573451/ toc-2316183/download

39. DIN Deutsches Institut für Normierung e.V. (1997) Prüfung fester Brennstoffe - Bestimmung des Aschegehaltes (Testing of solid fuels - Solid mineral fuels - Determination of ash content). in German(DIN 51719)

40. DIN Deutsches Institut für Normierung e.V. (2017) Biogene Festbrennstoffe Bestimmung des Heizwertes (Solid biofuels - Determination of calorific value) ISO 18125:2017(DIN EN ISO 18125)

41. Weißbach F (2008) Zur Bewertung des Gasbildungspotenzials von nachwachsenden Rohstoffen. Landtechnik 63(6): 356-358-356-358. Doi: https://doi.org/10.15150//t.2008.880

42. Hahne E (2010) Technische Thermodynamik. Einführung und Anwendung, 5., völlig überarb. Aufl. Oldenbourg, München

43. R development core team (2016) R. A language and environment for statistical computing. R Foundation for Statistical Computing, [Vienna]

44. Dragoni F, Giannini V, Ragaglini G et al (2017) Effect of harvest time and frequency on biomass quality and biomethane potential of common reed (Phragmites australis) under paludiculture conditions. BioEnergy Research 10(4):1066-1078. https://doi.org/10.1007/s12155-017-9866-z
45. Tölle R, Prochnow A, Kraschinski S (2000) Measuring methods for assessing the trafficability of fen grasslands. Landtechnik 55(3):218-219

46. Tong X, Smith LH, McCarty PL (1990) Methane fermentation of selected lignocellulosic materials. Biomass 21(4):239-255. https://doi.org/10.1016/ 0144-4565(90)90075-U

47. Weißbach F (2009) Wie viel biogas liefern Nachwachsende Rohstoffe? (how much biogas do renewable raw materials generate?). Neue Methode zur Bewertung von Substraten für die Biogasgewinnung (new method for evaluating substrates for biogas production). (in German). Neue Landwirtschaft 11:107-112

48. Clarke PJ, Jacoby CA (1994) Biomass and above-ground productivity of saltmarsh plants in South-Eastern Australia. Mar Freshw Res 45(8):1521. https:// doi.org/10.1071/MF9941521

49. Chambers JM, McComb AJ (1994) Establishing wetland plants in artificial systems. Water Sci Technol 29(4):79-84

50. Schönfeld-Bockholt R (2005) Das Salzgrünland der Ostseeküste Mecklenburg-Vorpommerns mit seinen häufigsten Pflanzen. Landwirtschaftlicher Wert, Naturschutzwert, ökologischer Zeigerwert, Erkennungsmerkmale der Pflanzen. Eigenverlag Agrar- und Umweltwiss. Fak. Rostock

51. Henneberg A, Elsgaard L, Sorrell BK et al (2015) Does Juncus effusus enhance methane emissions from grazed pastures on peat? Biogeosci Discuss 12(11):8467-8495. https://doi.org/10.5194/bgd-12-8467-2015

52. Prochnow A, Heiermann M, Plöchl M et al (2009) Bioenergy from permanent grassland - a review: 2. Combustion Bioresource Technol 100(21):4945-4954

53. Bauer A, Moeller L, Wedwitschka $\mathrm{H}$ et al (2018) Anaerobic digestion of mixed silage of waterweed biomass and wheat straw in a long-term semicontinuous biogas production process. Energ Sustain Soc 8(1):110. https:/ doi.org/10.1186/s13705-017-0145-9

54. Chanakya HN, Borgaonkar S, Meena G et al (1993) Solid phase fermentation of untreated leaf biomass to biogas. Biomass Bioenergy 5(5):369-377. https://doi.org/10.1016/0961-9534(93)90016-W

55. Li Y, Park SY, Zhu J (2011) Solid-state anaerobic digestion for methane production from organic waste. Renew Sust Energ Rev 15(1):821-826. https://doi.org/10.1016/j.rser.2010.07.042

56. Chanakya HN, Venkatsubramaniyam R, Modak J (1997) Fermentation and methanogenic characteristics of leafy biomass feedstocks in a solid phase biogas fermentor. Bioresour Technol 62(3):71-78. https://doi.org/10.1016/ S0960-8524(97)00139-9

57. Radwan AM, Sebak HA, Mitry NR et al (1993) Dry anaerobic fermentation of agricultural residues. Biomass Bioenergy 5(6):495-499. https://doi.org/10. 1016/0961-9534(93)90045-6

58. Poggi-Varaldo HM, Rodriguez-Vazquez R, Fernandez-Villagomez G et al. (1997) Inhibition of mesophilic solid-substrate anaerobic digestion by ammonia nitrogen. Appl Microbiol Biotechnol 47(3): 284-291. doi: https:// doi.org/10.1007/s002530050928

59. Müller J, Jantzen C, Kayser M (2012) The biogas potential of Juncus effusus L. using solid phase fermentation technique. Grassland Science in Europe 17:487-489

60. Nunes LIR, Matias JCO, Catalão JPS (2016) Biomass combustion systems: a review on the physical and chemical properties of the ashes. Renew Sust Energ Rev 53:235-242. https://doi.org/10.1016/j.rser.2015.08.053

61. Obernberger I, Brunner T, Bärnthaler G (2006) Chemical properties of solid biofuels_significance and impact. Biomass Bioenergy 30(11):973-982. https://doi.org/10.1016/j.biombioe.2006.06.011

62. van Meerbeek K, Appels L, Dewil R et al (2015) Energy potential for combustion and anaerobic digestion of biomass from low-input highdiversity systems in conservation areas. GCB Bioenergy 7(4):888-898. https:// doi.org/10.1111/gcbb.12208

\section{Publisher's Note}

Springer Nature remains neutral with regard to jurisdictional claims in published maps and institutional affiliations. 